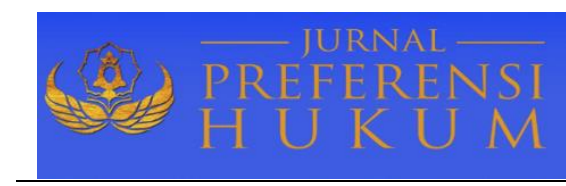

Jurnal Preferensi Hukum | ISSN: 2746-5039

Vol. 2, No. 1 -Februari 2021, Hal. 88-92| Available online at https://www.ejournal.warmadewa.ac.id/index.php/juprehum

DOI: https://doi.org/10.22225/jph.2.1.2800.88-92

\title{
PENYELESAIAN PERKARA HARTA WARISAN DAN HARTA BERSAMA DENGAN PROSEDUR MEDIASI DI PENGADILAN AGAMA BADUNG (NOMOR PERKARA 0095/PDTG/2017/PABDG)
}

\author{
I Kadek Leo Byasama Wijaya, I Nyoman Putu Budiartha, Ni Made Puspasutari Ujianti \\ Fakultas Hukum Universitas Warmadewa, Denpasar-Bali, Indonesia \\ kleobyasama46@gmail.com, budiarthal@gmail.com, puspasutari@gmail.com
}

\begin{abstract}
Abstrak
Konflik atau sengketa selalu ada pada setiap hubungan manusia dalam interaksi sosial, harta warisan bersama merupakan hal yang sering memicu konflik dalam keluarga diketahui bahwa tidak sedikit kasus tentang konflik yang diakibatkan oleh harta warisan yang masuk kepengadilan. Sengketa pada umumnya terjadi menyangkut hak dan kewajiban yang digolongkan dalam permasalahan perdata konflik dapat diselesaikan salah satunya dengan mediasi baik diluar pengadilan maupun di pengadilan. Mediasi dalam penyelesaian perkara perdata bisa dilakukan diawal litigasi maupun selama litigasi terhadap gugatan waris, gugatan harta bersama. Penyelesaian sengketa secara khusus mempunyai makna bahwa sengketa antara suami istri perbedaan pendapat diantara kedua belah pihak karena harta juga dapat mengacu pertikaian sehingga atas hal inilah terjadi suatu ketidakseimbangan kepemilikan dan perlu proses mediasi yang baik untuk menyetarakan kedudukan bagi kedua belah pihak. Penelitian ini bertujuan untuk menjelaskan kekuatan hukum mediasi didalam proses persidangan di Pengadilan Agama Badung, yang kedua untuk mengetahui tata cara pembagian harta warisan dan harta bersama menurut kompilasi Hukum Islam. Jenis penelitian yang digunakan adalah penelitian hukum empiris dengan pendekatan yuridis sosiologis. Data yang digunakan adalah bersumber dari data hukum primer dan sekunder yang dianalisis secara kualitatif. Hasil penelitian ini menunjukan bahwa Kekuatan Hukum mediasi di dalam proses persidangan di Pengadilan Agama Badung yaitu dengan adanya akta perdamaian maka hasil dari kesepakatan perdamaian tersebut mendapat kepastian hukum, yang kedua pembagian harta warisan bersama menurut kompilasi Hukum Islam yaitu seorang suami ataupun istri mendapat bagian sama separuh karna dilihat juga berdasarkan rasa keadilan atau itikad baik dari salah satu pihak.
\end{abstract}

Kata Kunci: Harta Warisan; Mediasi; Hukum Islam

\begin{abstract}
Conflict or disputes always exist in every human relationship in social interactions, shared inheritance is something that often triggers conflict in the family. It is known that there are not a few cases of conflict caused by inheritance that go to court. Disputes generally occur regarding rights and obligations which are classified as civil conflict issues. One of them can be resolved by mediation either out of court or in court. Mediation in civil case settlement can be carried out at the beginning of litigation or during litigation against inheritance claims, joint property claims. Dispute resolution specifically means that disputes between husband and wife are differences of opinion between the two parties because property can also refer to a dispute so that in this case an imbalance of ownership occurs and a good mediation process is needed to equalize the position of the two parties. This study aims to explain the legal power of mediation in the trial process at the Badung Religious Court, the second is to find out the procedures for the distribution of inheritance and collective assets according to the compilation of Islamic Law. This type of research is empirical legal research with a sociological juridical approach. The data used are sourced from primary and secondary legal data which were analyzed qualitatively. The results of this study indicate that the legal power of mediation in the trial process at the Badung Religious Court, namely by the existence of a peace deed, the results of the peace agreement receive legal certainty, secondly, the distribution of joint inheritance according to the compilation of Islamic Law, namely that a husband or wife gets an equal share of half because it is seen also based on a sense of justice or goodwill from one of the parties.
\end{abstract}

Keywords: Inheritance; Mediation; Islamic law

\section{PENDAHULUAN}

Al-Qur'an merupakan sumber hukum dari Agama Islam yang didalamnya terdapat tatanan serta aturan yang mengatur kehidupan umatnya baik di dunia ataupun diakhirat (Taufik, 2016). Hukum Islam adalah suatu norma yang dijadikan sebagai pedoman untuk mengatur antara hubungan manusia 
dengan manusia, manusia dengan benda, ataupun manusia dengan tuhannya, dalam Hukum Islam terdapat berbagai aspek yang diaturnya, antara lain mengenai warisan hibah (Khisni \& A, 2013). Waris yang dimaksud disini yaitu harta kekayaan ataupun hutang yang ditinggalkan untuk ahli waris dari pewarisnya karena sudah meninggalnya pewaris.

Menurut Nasution, (2012) Hukum waris merupakan suatu peraturan yang mengatur berbagai aspek mengenai warisan karena telah meninggalnya seorang pewaris kepada ahli warisnya atau siapapun yang diberikan oleh pewaris, dalam hukum waris diatur berbagai hal untuk mengalihkan waris tersebut kepada ahli waris ataupun yang ditunjuk baik itu berupa harta ataupun hutang piutang yang ditinggalkan oleh pewaris. Dalam hukum waris islam seorang anak laki-laki maupun anak perempuan sama-sama mempunyai hak untuk mendapat bagian waris baik dari ibunya ataupun bapaknya baik itu hanya sebagian ataupun seluruhnya dari waris yang ditinggalkan oleh pewaris.

Berdasarkan Hukum Islam pewarisan hanya dapat terjadi apabila terpenuhinya berbagai persyaratan yang telah diatur dalam waris Hukum Islam, pewarisan tersebut terjadi apabila ada hubungan kekerabatan dengan pewaris ataupun pewaris telah meninggal dunia. Pewarisan tidak dapat terjadi jika salah satu syarat tersebut tidak terpenuhi. Perkawinan merupakan suatu ikatan lahir dan batin antara seorang laki-laki dengan perempuan sebagai suami istri dengan maksud membentuk suatu keluarga (rumah tangga) yang bahagia dan kekal berdasarkan Ketuhanan Yang Maha Esa. Hak adalah sesuatu yang seharusnya diterima seseorang setelah ia memenuhi kewajibannya sedangkan kewajiban adalah sesuatu yang seharusnya dilaksanakan oleh seseorang untuk mendapatkan hak Suami istri wajib saling setia dan mencintai hormat-menghormati dan saling memberi bantuan secara lahir dan batin (Khisni \& A, 2013).

Jika dalam keluarga mengalami konflik sampai pada tahap perceraian maka perlu ditelusuri mana harta yang memang diperoleh pada saat pernikahan sudah terjadi dan mana harta yang dibawa oleh masing-masing pihak suami dan istri. Menurut Faizal, (2015) Dalam Hukum Islam harta gono gini ataupun harta bersama merupakan sama harta bersama baik itu diperoleh saat perkawinan sudah terjadi atau dibawa sebelum perkawinan terjadi. Tetapi yang harus di perjelas yaitu harta gono gini, mana yang dibawa oleh suami istri sebelum perkawinan terjadi agar kemudian hari tidak terjadi permasalahan suami mengambil hak dari harta yang dibawa istri dan juga sebaliknya iastri mengambil hak dari harta yang dibawa suami. Permasalahan yang timbul akibat harta bersama yaitu adanya percampuran antara harta bersama dengan harta warisan. Ini yang sering terjadi karena pembagian harta waris pada saat perkawinan tersebut sudah terjadi sehingga adanya percampuran antara harta warisan dan harta bersama karena harta warisan tersebut memang dipergunakan untuk kepentingan keluarga (Satrio 1991189). Percampuran harta warisan tersebut sering menimbulkan sengketa sebelum terjadi perceraian. Penyelesaian sengketa secara khusus mempunyai makna bahwa sengketa yang terjadi antara suami istri perbedaan pendapat diantara kedua belah pihak karena harta juga dapat mengacu pertikaian. Sehingga atas hal inilah terjadi suatu ketidakseimbangan kepemilikan dan diperlukan adanya suatu kebijakan untuk menyetarakan kedudukan bagi kedua belah pihak.

Ada beberapa penelitian terdahulu yang releven dengan penelitian ini pertama Waha, (2013) Pembagian harta bersama dalam perkawinan (gono-gini) perlu didasarkan pada aspek keadilan untuk semua pihak yang terkait keadilan yang dimaksud mencakup pada pengertian bahwa pembagian tersebut tidak mendiskriminasikan salah satu pihak. Menurut Bahrun, (2018) hasil penelitiannya mengungkapkan bahwa mediator belum mampu secara maksimal menjembatani kepentingankepentingan yang berbeda dari pihak-pihak yang berselisih. Penelitian selanjutnay mengungkapkan bahwa jika pada pihak seiman atau sama agama, maka dilakukan oleh pemangku adat dan atau tokoh masyarakat yang dituakan sebab masyarakat lebih cenderung memakai jasa pemangku adat untuk menyelesaikan perkara (Palanai \& Saleh, 2018). Penelitian ini bertujuan untuk mengetahui kekuatan hukum mediasi dalam proses persidangan di Pengadilan Agama Badung, yang kedua untuk mengetahui tata cara pembagian harta warisan dan harta bersama menurut kompilasi Hukum Islam.

\section{METODE PENELITIAN}

Penelitian ini didesain dengan penelitian hukum empiris. Penelitian hukum empiris merupakan penelitian yang berkaitan dengan hukum dan perilaku manusia. Sumber data data yaitu data primer diperoleh dari hasil wawancara langsung dari narasumber dan responden, wawancara ini dilakukan 
dengan informan serta suatu pedoman yang adalah diperoleh melalui media perantara atau secara tidak langsung yang berupa buku catatan bukti yang telah ada atau arsip baik yang dipublikasikan maupun yang tidak dipublikasikan secara umum yang terdiri dari bahan hukum primer dan bahan hukum sekunder termasuk juga literatur kamus beserta tulisan ilmiah lainnya yang berkaitan dengan pokok permasalahan yang dikaji. Pendekatan yang digunakan adalah yuridis sosiologis yang terkait dengan pelaksanaan penjualan pakaian bekas impor di Kota Denpasar. Pendekatan yuridis sosiologis adalah suatu penelitian yang dilakukan terhadap keadaan nyata yang terjadi dimasyarakat bertujuan untuk menemukan fakta-fakta atau permasalahan yang ada dan menuju pada identifikasi, akhirnya menuju pada penyelesaian masalah

\section{HASIL DAN PEMBAHASAN}

\section{Kekuatan Hukum Mediasi dalam Proses Persidangan}

Mediasi merupakan cara penyelesaian sengketa ataupun permasalahan hukum lainnya melalui proses perundingan atau musyawarah untuk memperoleh kesepakatan para pihak yang dibantu oleh mediator. Posisinya Mediator berada pada posisi tengah dan netral antara para pihak yang bersengketa dan mengupayakan menemukan sejumlah kesepakatan sehingga mencapai hasil yang memuaskan para pihak yang bersengketa kedua belah pihak memilih mediatornya masing masing dengan pilihan hakim yang ada dipengadilan yang bukan merupakan hakim yang menangani perkara tersebut, mediator tersebut juga harus bersertifikat yang telah diakui oleh perundang-undangan.

Pelaksanaan mediasi dilakukan kesepakatan antara kedua belah pihak mediasi tidak dibuka secara umum seperti sidang umum pada biasanya kecuali adanya kesepakatan kedua belah pihak. Mediasi pada umumnya dilaksanakan disalah satu ruangan yang berada dilingkungan pengadilan tempat perkara tersebut diajukan. Berdasrkan aturan perundangan yang baru jangka waktu untuk melaksanakan mediasi lebih dipersingkat 10 hari. Masing-masing para pihak yang didampingi kuasa hukum bagi yang menggunakan jasa kuasa hukum dan juga dapat diwakilkan oleh kuasa hukum apabila pihak yang bersangkutan tidak bisa hadir karena sakit dan disertai dengan surat sakit dari dokter ataupun karena keterbatasan jarak dari pihak yang bersangkutan, dan punya kepentingan yang tidak dapat ditinggalkan terlebih lagi pekerjaan yang dilakukan untuk tugas dari negara.

Akta perdamaian dibuat ketika kedua belah pihak telah mencapai kesepakatan pada saat mediasi yang didampingi oleh mediator yang diakui oleh peraturan perundang-undangan. Dalam akta perdamaian yang mempunyai hak untuk memutuskan yaitu seorang hakim yang nantinya akta perdamaian tersebut akan dilampirkan dalam putusan hakim. Akta perdamaian yang dibuat berdasarkan kesepakatannya kedua belah pihak mempunyai kekuatan hukum yang setara dengan putusan hakim, oleh karena itu kesepakatan yang telah terjadi dan dituangkan dalam akta perdamaian tidak dapat dibantah dengan alasan apapun termasuk ada salah satu pihak yang merasa dirugikan.

Fungsinya akta perdamaian sama dengan perjanjian seperti biasa yang mengikat kedua belah pihak yang nantinya akan dijadikan sebagai bukti dari kesepakatan dari kedua belah pihak. Akta tersebut yang nantinya hanya mengikat para pihak yang bersepakat saja akan tetapi didampingin oleh seorang mediator untuk mencapai kesepakatan tersebut. Mediator harus berlaku netral, karena apapun keinginan dari kedua belah pihak nantinya akan menjadi kesepakatan dari kedua belah pihak, apabila kemudian hari terjadi permasalahan kembali makan salah satu pihak harus mengajukan perkara tersebut, akan tetapi pada perkara yang baru putusan tersebut tidak dapat dieksekusi (Wiantara, 2018).

\section{Cara Pembagian Harta Warisan Bersama Menurut Kompilasi Hukum Islam.}

Dalam Hukum Islam kata waris merupakan kata yang diambil dari bahasa arab yang mempunyai arti mewaris jika dihubungkan dengan kondisi yang berkembang saat ini istilah waris dapat diartikan sebagai suatu perpindahan hak ataupun kewajiban termasuk harta kekayaan seseorang pewaris kepada ahli waris hukum yang mengatur pembagian harta warisan yang ditinggalkan oleh ahli waris mengetahui bagian-bagian yang diterim dari peninggalan setiap ahli waris yang berhak menerimanya (Ahmad Warsom Al- Munawir19971655).

Menurut Manan, (2006) Harta bersama merupakan harta yang diperoleh oleh suami istri ketika perkawinan tersebut sudah terjadi jadi harta bersama merupakan harta benda yang menjadi harta bersama yang didapatkan oleh seorang suami istri saat perkawinan sudah terjadi. Harta bersama 
diperoleh pada saat sudah terjadinya ikatan perkawinan baik itu dengan usaha masing-masing ataupun melalui kerjasama dari pihak suami istri pada saat perkawinan sudah terjadi.

Suami atau istri tanpa persetujuan dari salah satu pihak tidak diperbolehkan menjual atau memindahkan harta bersama tersebut dalam hal ini baik suami maupun istri. Masing-masing mempunyai pertanggungjawaban untuk menjaga harta bersama pertanggungjawaban hutang dari seorang suami atau istri dikembalikan pada masing-masing pihak. Apabila terjadi hutang untuk kepentingan bersama atau kepentingan keluarga makan hutang tersebut diselesaikan menggunakan harta bersama, juka hutang tidak dapat terselesaikan menggunakan harta bersama maka hutang tersebut dibebankan dalam harta suami dan istri.

Harta besama menurut Hukum Islam adalah suatu harta yang diperoleh oleh pihak suami istri apabila dalam memperoleh harta tersebut dengan adanya kerjasama berdua tidak diperoleh dengan jerih payah sendiri, apabila kemudian hari salah satu pihak meninggal atau terjadi perceraian maka harta tersebut dibagi sama rata karena diperoleh dengan kerjasama. Harta bersama dalam suatu perkawinan ditujukan untuk dapat memenuhi kebutuhan keluarga tersebut baik untuk seorang suami, seorang istri ataupun seorang anak oleh karena itu untuk dapat menggunakan harta bersama tersebut haruslah berdasarkan pada keputusan oleh kedua belah pihak suami ataupun istri, karena harta bersama tersebut tidak bisa dikuasai oleh salah satu pihak saja.

Pembagian harta bersama dalam Hukum Islam pada saat terjadinya perceraian maka tata cara pembagian harta bersama menurut hukum kedua mempelai. Apabila kedua mempelai bergama islam maka pembagian harta bersama dilakukan berdasarkan Hukum Islam ataupun kompilasi Hukum Islam, jika salah satu mempelai berbeda agama makan pembagian harta bersama dilakukan berdasarkan pada hukum perdata yang berlaku ataupun berdasarkan pada hukum adatnya.

Pembagian harta bersama yang diatur dalam Hukum Islam merupakan suatu wujud untuk menumbuhkan rasa keadilan bagi semua pihak karena dalam pembagian harta bersama tidak memandang siapakah yang mendapatkan pengasilan tersebut pada saat perkawinan tersebut terjadi. Akan tetapi disini muncul suatu pertanyaan mungkinkah pengaturan mengenai pembagian harta bersama itu bisa terjadi untuk semua golongan ataupun hanya berlaku untuk golongan tertentu yang berkepentingan saja (Harahap, 1989).

Ketentuan pembagian harta bersama separuh bagi suami dan separuh bagi istri hanya sesuai dengan rasa keadilan dalam hal baik suami maupun istri sama-sama melakukan peran yang dapat menjaga keutuhan dan kelangsungan hidup keluarga. Suami atau istri berhak atas separuh harta bersama adalah berdasarkan peran yang dimainkan baik oleh suami atau istri sebagai partner yang saling melengkapi dalam upaya membina keutuhan dan kelestarian keluarga.

Dalam perkawinan ada yang dimaksud dengan harta gono gini, apabila kemudian hari terjadinya suatu perceraian maka pembagian harta gono gini tersebut dapat dilakukan pada musyawarah mufakat antara kedua belah pihak dan dapat juga berdasarkan putusan dari pengadilan. Musyawarah ataupun putusan pengadilan tidak selalu pembagian harta tersebut diputuskan dengan pembagian persentase 50\% tetapi bisa saja lebih, disini perlu ditelusuri manakah pihak yang memang membawa harta lebih banyak ataupun mana yang lebih sedikit. Pertimbangan pembagian harta gono gini seorang hakim harus melihat permasalahan tersebut mana yang memang benar membawa harta lebih banyak ataupun mana yang lebih sedikit, karena sering terjadi yang membawa harta lebih sedikit menuntut untuk mendapat lebih banyak ataupun setara dengan yang membawa harta lebih banyak.

\section{SIMPULAN DAN SARAN}

\section{Simpulan}

Berdasarkan analisis data dapat disimpulkan bahwa kekuatan hukum mediasi dalam proses persidangan di Pengadilan Agama Badung yaitu dengan adanya akta perdamaian atau surat perdamaian maka hasil dari kesepakatan perdamaian tersebut mendapat kepastian hukum bahkan memiliki kekuatan eksekutorial atau memiliki kekuatan hukum sama dengan putusan pengadilan, yang kedua pembagian harta warisan dan harta bersama menurut kompilasi Hukum Islam yaitu seorang suami ataupun istri mendapat bagian sama separuh karna dilihat juga berdasarkan rasa keadilan atau itikad baik dari salah satu pihak. Karena dalam berkeluarga bukan hanya dilihat siapa yang mendapatkan harta tersebut tapi 
salah satu pihak mempunyai perannya masing-masing, disinilah harus menonjolkan rasa keadilan dan itikad baik dari kedua pihak.

\section{Saran}

Adapun yang perlu disarankan oleh peneliti yaittu diharapkan kepada Pengadilan Agama harus terus mengutamakan mediasi terlebih dahulu agar terciptanya keadilan antara penggugat dan tergugat sehingga masih ada jalan untuk berdamai antara penggugat dan tergugat, selanjutnay diharapkan kepada masyarakat untuk lebih menekankan pada dasar atas keadilan maka tata cara pembagian harta warisan ini seharusnya bisa lebih efisien sehingga pembagian harta warisan sama rata antara suami dan istri.

\section{DAFTAR PUSTAKA}

Bahrun. (2018). Peranan Hakim Mediator dalam Penyelesaian Sengketa Harta Bersama Pasca Perceraian. Law Jurnal, 2(3), 371-387.

Faizal, L. (2015). Harta Bersama dalam Perkawinan. Ijtimaiyya, 8(2), 77-102.

Harahap, M. Y. (1989). Kedudukan Kewenangan dan Acara Peradilan Agama. Sinar Grafika.

Khisni, \& A. (2013). Aliran-Aliran Pemikiran dalam Hukum Islam. Unissula Press.

Manan, A. (2006). Aneka Masalah Hukum Perdata Islam di Indonesia. Kencana.

Nasution, A. H. (2012). Hukum Kewarisan. PT Raja Grafindo Persada.

Palanai, A., \& Saleh, A. (2018). Sistem Pembagian Harta Gono Gini Adat Tolotang di Kabupaten Sidrap. Petitum, $6(2), 112-121$.

Taufik, I. (2016). Dinamika Hukum Islam di Indonesia. Deepublish.

Waha, F. M. (2013). Penyelesaian Sengketa atas Harta Perkawinan Setelah Bercerai. Lex et Socialis, 1(1), 54-64. Wiantara, I. K. (2018). Penyelesaian Perkara Perdata di Pengadilan Berdasarkan Peraturan Mahkamah Agung Republik Indonesia Nomor 1 Tahun 2016. Jurnal Magister Hukum Udayana (Udayana Master Law Journal), 7(4), 456. 